\title{
Factors Affecting The Customer Saving in KC Singkawang Bank Syariah Mandiri
}

\author{
Maulina Fera1), Wui San Taslim ${ }^{2)}$ \\ 1) Politeknik Tongak Equator, Pontianak, Indonesia \\ E-mail: fmauli.defasa@gmail.com \\ 2) Politeknik Tongak Equator, Pontianak, Indonesia \\ E-mail: siau_se_lin@yahoo.com
}

\begin{abstract}
This study aims to determine how much influence the product factor, quality of services provided, offered profit sharing ratio and religiosity factor customers to save customers' interest in Bank Syariah Mandiri (BSM) KC Singkawang. The research location is in Singkawang, where people Singkawang has a multi-ethnic city that consists of three (3) the largest ethnic Chinese, Malay and Dayak. This underlying this research. The method used is an associative method, the data collection technique of distributing questionnaires to the respondents to explore related information about the factors that affect customers save on BSM KC Singkawang. This research resulted in the coefficient of determination (R2) of 0443 which means that the variable products, services, revenue sharing and religiosity can explain the customer's decision in BSM KC Singkawang saving of $44.3 \%$. While the remaining $55.7 \%$ is influenced by other factors not included in this research model.
\end{abstract}

Keywords: product, service quality, revenue sharing, religiosity

\section{Introduction}

In the world of banking, Islamic banks is a relatively new service industries, which apply Islamic law in any banking activity. The enactment - Act 10 of 1998 on the banks governing Islamic banks are sufficiently clear and strong institutional and operational terms, which was amended by Law No. 23 of 1999 concerning Bank Indonesia and the Law 3 of 2004. This triggered the growth of Islamic banks in Indonesia.

Islamic banks in Indonesia established since wishes of the people, especially people who are Muslims who think the interest is unlawful, it was further strengthened with the opinion of the scholars in Indonesia, represented by the MUI No. 1 of 2004 on the interest that essentially forbid bank interest in which there are elements - elements of usury.

The existence of Islamic banking development has caused many significant differences, especially in terms of pricing and compensation for the use of funds. Islamic banking is an intermediary institutions that provide financial services to the community in 
which all activities are run by the ethics and principles of Islam, free from the element of riba (interest), free of speculative non-productive activities such as gambling (maysir), free of dubious activities (gharar), free from illegitimate cases (false), and only pay for the lawful efforts. In operation, the Islamic banks provide and wear a reward on the basis of Islamic principles of sale and the bank's results so often equated with the bank without interest (Ershad Lubis, 2010: 101).

The system of interest (interest or usury) is aimed at optimizing the fulfillment of personal interests that did not consider the social impacts caused. In contrast to the system for the results, this system-oriented fulfillment of life benefit of mankind (Heri Sudarsono, 2007: 20).

In other words, Islamic banking was established based on the philosophical and practical reasons. Philosophical reason is the prohibition of riba in financial and non-financial transactions.

\section{Method}

The method used is an associative method. According to Riduwan (2010), associative methods are problems connecting or influence between the two variables or more. But analysis of the data used is quantitative analysis using SPSS for Windows version 16.0

\section{Data Collection Techniques}

Data collection techniques in this study through interviews and questionnaires by respondents. Questionnaires were administered to respondents in this study contains a closed question, ie a question that alternative answers have been provided, so that respondents only choose one answer he thought most appropriate. The method to determine the respondent is done by simple random sampling method by taking the number of respondents as many as 50 people.

\section{Variables and Indicators Research}

Variables used in this research is the independent variable in the form of factor products, services, revenue sharing and religiosity. The dependent variable in the form: the interest of saving the customer.

1. The independent variable

a. factor product, the indicator is:

1) Excellence savings products offered

2) Variations savings products offered

3) guarantee the security provided

4) Completeness products offered

5) savings products are offered in accordance with the needs of society

b. Factor Services, the indicator is:

1) Clarity and ease of product information from employees of Bank Syariah Mandiri KC Singkawang

2) ease in transacting 
3) provision of adequate facilities

4) of Bank Syariah Mandiri KC Singkawang has many cash offices to facilitate the transaction

5) Courtesy employees of Bank Syariah Mandiri KC Singkawang

c. Factor Ratio Profit Sharing, the indicator is:

1) Clarity system for the results of a given

2) system for a given outcome gives a sense of comfortable

3) the ratio for a given outcome is more competitive than another Islamic bank

4) presence of the economic benefits ratio for a given outcome

5) ensured fairness in the system for a given outcome

d. Religiosity factor, the indicator is:

1) Product services offered is a good product and lawful

2) understanding of respondents to the principles of Islamic

3) the principle of sharia will bring blessing and good benefits

4) savings products that are offered free of elements of usury

5) Employees of Bank Syariah Mandiri KC Singkawang behave Islami

2. The dependent variable, namely: Interest saving customers, the indicators:

a. intensity save customers

b. Inviting close relatives to save money in Bank Syariah Mandiri KC Singkawang

c. amount of initial deposit offered affordably

d. availability of an ATM

e. Location Bank Syariah Mandiri KC Singkawang easily affordable

\section{Result and Discussion}

\section{Test Validity Questionnaire}

test the validity of the testing techniques Corrected Item-Total Correlation by way of correlating each item score with a total score and make corrections to the correlation coefficient values overestimation.

Tests using two-sided tests with a significance level of 0.05 . Testing criteria are as follows:

1. If the count $r \geq r$ table (test 2 sides with the sig. 0.05 ), the instruments or items significantly correlated questions to the total score (declared invalid).

2. If the count $\mathrm{r}<\mathrm{r}$ table (test 2 sides with the sig. 0.05), the instruments or items no questions correlated significantly to the total score (declared invalid).

As for the validity of the test will be performed for the variable $X$ (Products, Services, Ratio Profit Sharing and Religiosity) and Y (Saving Decision).

Variable X (Products, Services, Ratio Profit Sharing, and Religiosity) 
Table 1 Test Validity Questionnaires variable $X$

\begin{tabular}{|c|c|c|c|c|}
\hline \multicolumn{5}{|c|}{ item-Total Statistics } \\
\hline & $\begin{array}{c}\text { Scale Mean if Item } \\
\text { Deleted }\end{array}$ & $\begin{array}{l}\text { Scale Variance if } \\
\text { Item Deleted }\end{array}$ & $\begin{array}{l}\text { Corrected Item- } \\
\text { Total Correlation }\end{array}$ & $\begin{array}{c}\text { Cronbach's Alpha if } \\
\text { Item Deleted }\end{array}$ \\
\hline $\mathrm{X} 1 \mathrm{~A}$ & 80.5400 & 35845 & & .352 .875 \\
\hline $\mathrm{x} 1 \mathrm{~b}$ & 36,539.188.880 & & & 80.5400 \\
\hline $\mathrm{x} 1 \mathrm{c}$ & 80.3200 & 35202 & .401 & .874 \\
\hline$x 1 d$ & $34,458.573 .869$ & & & 80.4600 \\
\hline $\mathrm{x} 1 \mathrm{e}$ & 80.4000 & 34082 & .616 & .868 \\
\hline $\mathrm{x} 2 \mathrm{a}$ & $35,086.423 .873$ & & & 80.3400 \\
\hline$x 2 b$ & 80.4000 & 34571 & .480 & .871 \\
\hline $\mathrm{x} 2 \mathrm{c}$ & $35,855.365 .875$ & & & 80.6800 \\
\hline$x 2 d$ & $31,682.392 .887$ & & & 81.4600 \\
\hline$x 2 e$ & 80.2800 & 33798 & .646 & .866 \\
\hline $\mathrm{x} 3 \mathrm{a}$ & 34,131.701.866 & & & 80.5400 \\
\hline$x 3 b$ & 80.5800 & 34371 & .557 & .869 \\
\hline $\mathrm{x} 3 \mathrm{c}$ & $33,870.513 .870$ & & & 80.7400 \\
\hline $\mathrm{X} 3 \mathrm{D}$ & 80.7600 & 35329 & .369 & .875 \\
\hline $\mathrm{x} 3 \mathrm{e}$ & .324 .876 & 35,500 & & 80.6400 \\
\hline $\mathrm{x} 4 \mathrm{a}$ & 33,827.651.866 & & & 80.3600 \\
\hline $\mathrm{x} 4 \mathrm{~b}$ & 80.6000 & 33714 & .512 & .870 \\
\hline $\mathrm{x} 4 \mathrm{c}$ & 33,739.608.867 & & & 80.3400 \\
\hline $\mathrm{x} 4 \mathrm{~d}$ & 80.5200 & 32255 & .723 & .862 \\
\hline $\mathrm{x} 4 \mathrm{e}$ & 33,732.607.867 & & & 80.3200 \\
\hline
\end{tabular}

Table 2 validity Questionnaires variable $Y$

\begin{tabular}{lrrrr}
\hline & \multicolumn{2}{c}{ Item-Total Statistics } \\
\hline & $\begin{array}{c}\text { Scale Mean if } \\
\text { Item Deleted }\end{array}$ & $\begin{array}{c}\text { Scale Variance if } \\
\text { Item Deleted }\end{array}$ & $\begin{array}{c}\text { Corrected Item-Total } \\
\text { Correlation }\end{array}$ & $\begin{array}{c}\text { Cronbach 's Alpha if } \\
\text { Item Deleted }\end{array}$ \\
\hline y1 & 17.2400 & 2,758 & .529 & .788 \\
y2 & 17.2800 & 2,573 & .767 & .719 \\
y3 & 17.2600 & 2727 & .718 & .738 \\
y4 & 17.0800 & 2,932 & .477 & .801 \\
y5 & 17.3000 & 2,459 & .543 & .795 \\
\hline
\end{tabular}

From the analysis, it can be seen that no item of less than 0.285 , it can be concluded that the clause is a valid instrument. If the validity of the test has been performed and found items are valid questions, it will proceed with normality test.

\section{Normality Test}

Normality test used to determine whether a population of the normal distribution of data or not. If analysis using parametric methods, the requirements must be met and that the normality of the data comes from a normal distribution. If the data are not normally distributed, or sample a little bit and kind of data are nominal or ordinal, then the method used is a non-parametric statistics. In this discussion will be used to test the One Sample Kolmogorov-Smirnovdengan using a significance level of 0.05. Data are expressed in normal distribution if the significance is greater than $5 \%$ or 0.05 . 
Table 3 Normality Test

\begin{tabular}{|c|c|c|c|c|c|c|}
\hline \multicolumn{7}{|c|}{ Tests of normality } \\
\hline & \multicolumn{3}{|c|}{ Kolmogorov-Smirnov ${ }^{\mathrm{a}}$} & \multicolumn{3}{|c|}{ Shapiro-Wilk } \\
\hline & Statistic & df & Sig. & Statistic & df & Sig. \\
\hline Products & $\begin{array}{r}.000 \\
.826 .000\end{array}$ & 49 & & & 49 & .255 \\
\hline Care & $\begin{array}{r}.000 \\
.929 .000\end{array}$ & 49 & & & 49 & .134 \\
\hline revenue sharing & $\begin{array}{r}.000 \\
.848 .000\end{array}$ & 49 & & & 49 & .287 \\
\hline Religiosity & $\begin{array}{r}.000 \\
.847 .000\end{array}$ & 49 & & & 49 & .237 \\
\hline saving decision & .245 & $\begin{array}{r}.000 .85649 \\
.000\end{array}$ & & & & 49 \\
\hline Lag_Y & .864 & .00049.000. & & .243 & & 49 \\
\hline
\end{tabular}

a. Significance Lilliefors Correction

From the above results we see in the column Kolmogorov-Smirnov test and it is known that significant value for Saving Decree 0,000; for $\mathrm{X} 10,000 ; \mathrm{X} 2=0.000, \mathrm{X} 3=0.000$, and $\mathrm{X} 4=0.000$. Because of the significance of all the variables is smaller than 0.05 , it can be concluded that the data on saving decision variables, products, services, revenue sharing and religiosity significance because the normal distribution is not less than $5 \%$ or 0,05 maka statistical methods used are nonparametric

\section{BLUEtest}

Before testing of the hypothesis needs to be evaluated against the econometric regression model in order to qualify as a Best Linear Unbiased Estimator (BLUE).Evaluasi econometrics in this study consisted of classic assumption test.

\section{Test Multicollinearity}

The multikolinearitas test is used to determine whether or not the classic assumption deviation multikolinearitas ie linear relationship between the independent variables in the model regression. Prerequiesed that must be met in the regression model is the absence of multicollinearity.

The test method used is to look at the value of the inflation factor (VIF) in regression models. In general, if VIF is greater than 5, the variables have multikolinearitas problems with other independent variables.

Table 4 Test Multicollinearity

\begin{tabular}{llrrrrr}
\hline \multicolumn{5}{c}{ Coefficients } \\
\hline \multicolumn{1}{c}{ Correlations } & \multicolumn{3}{c}{ collinearity Statistics } \\
\cline { 3 - 7 } & \multicolumn{2}{c}{$\begin{array}{c}\text { Model- } \\
\text { orderZero }\end{array}$} & Partial & Part & Tolerance & VIF \\
\hline 1 & .407 & .260 & .201 & .635 & 1,575 \\
& Products & .475 & .077 & .058 & .573 & 1,744 \\
& Services & .507 & .346 & .276 & .550 & 1,818 \\
& revenue sharing & .185 .140 .501 & & & .557 & 1,994 \\
& Religiosity & .078 .058 .839 & & & .094 & 1,192 \\
Lag_Y & & & & & & \\
\end{tabular}


a. Dependent Variable: saving decisions

\begin{tabular}{|c|c|c|c|}
\hline \multicolumn{4}{|c|}{ Correlations } \\
\hline & & & Residual unstandardized \\
\hline \multirow[t]{21}{*}{ Spearman's rho } & \multirow[t]{3}{*}{ product. } & correlation coefficient & .066 \\
\hline & & Sig (2-tailed) & .655 \\
\hline & & $\mathrm{N}$ & 49 \\
\hline & \multirow[t]{3}{*}{ services } & Correlation Coefficient & -.012 \\
\hline & & Sig. (2-tailed) & .935 \\
\hline & & $\mathrm{N}$ & 49 \\
\hline & \multirow[t]{3}{*}{ sharing ratio } & Correlation Coefficient & .085 . \\
\hline & & Sig (2-tailed) & .563 \\
\hline & & $\mathrm{N}$ & 49 \\
\hline & \multirow[t]{3}{*}{ religiosity } & Correlation Coefficient & .087 . \\
\hline & & Sig (2-tailed) & .553 \\
\hline & & $\mathrm{N}$ & 49 \\
\hline & \multirow[t]{3}{*}{ decisionsave } & Correlation Coefficient & $.791^{* *}$ \\
\hline & & Sig. (2-tailed) & .093 \\
\hline & & $\overline{\mathrm{N}}$ & 49 \\
\hline & \multirow[t]{3}{*}{ Lag_Y } & Correlation Coefficient & -.034 \\
\hline & & Sig. (2-tailed) & .816 \\
\hline & & $\bar{N}$ & 49 \\
\hline & \multirow[t]{3}{*}{ unstandardized Residual } & Correlation Coefficient & 1.000 \\
\hline & & Sig. & (2-tailed) \\
\hline & & $\mathrm{N}$ & 49 \\
\hline
\end{tabular}

**. Correlation is significant at the 0:01 level (2-tailed).

From the above results it can be seen, the variance inflation factor (VIF) four variables ie products, services, revenue sharing and religiosity is less than 5, so it can be expected that an independent variable multikolinearitas problem does not occur.

\section{Test Heteroskedasticity}

the heteroskedastisitas test is used to determine whether or not the classic assumption deviation heteroskedasticity namely inequality variants of residuals for all observations on regression. Prerequised models that must be met in the regression model is the absence of symptoms heteroscedasticity.

\section{Spearman's Correlation Coefficient Test Rho}

drunken The testing method is Spearman's correlation coefficient test rho.Metode heteroscedasticity test with Spearman's correlation Tho ie independent variables correlate with unstandardized residual.Pengujian value using a 0.05 significance level to test the two sides. If the correlation between the independent variables with the residual can be of significantly greater than 0.05 , it can be said that there was no trouble heteroscedasticity in regression models.

From the above output can be seen that the correlation value of four independent variables with unstandardized Residual has a significance value of 0.05 . Because of the 
significance greater than 0.05 , it can be concluded that there was no trouble heteroscedasticity in regression models.

\section{Scatterplot Test}

This method is a way to see the scatterplot graph between the standardized predicted value (ZPRED) with residual studentized (SREID). Whether there is a specific pattern on a scatterplot graph between SRESID and ZPRED wherein $\mathrm{Y}$ is a $\mathrm{Y}$ axis that has been predicted and $\mathrm{X}$-axis is the residual (prediction $\mathrm{Y}-\mathrm{Y}$ real).

Basis for a decision that is:

1. If there is a specific pattern, such as the existing dots form a certain regular pattern (wavy, widened and then narrowed), then their heteroscedasticity.

2. If there is no clear pattern, like dots spread above and below the number 0 on the $\mathrm{Y}$ axis, then there is no heteroscedasticity.

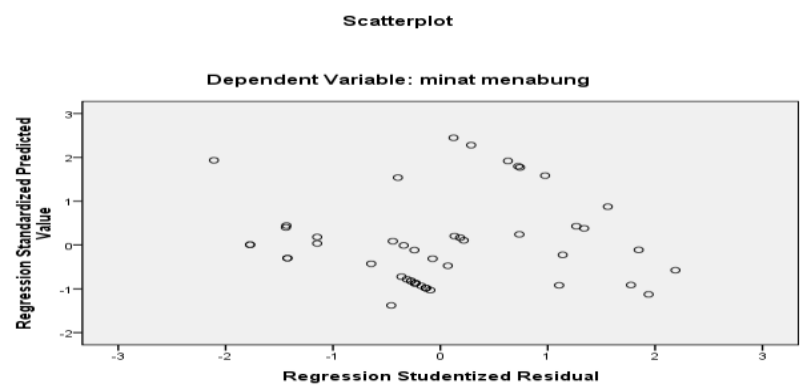

Fig. 1 Test scatterplot

From the output above it can be seen that the points do not form a clear pattern, and the points spread above and below the number 0 on the $\mathrm{Y}$ axis so it can be concluded that there was no trouble heteroscedasticity in the regression model.

\section{Autocorrelation test}

autocorrelation test is used to determine whether or not the classic assumption deviation autocorrelation is the correlation between the residuals on the observation by other observations in the regression model. Prerequisites that must be met is the absence of autocorrelation in the regression model. A method frequently used test is the test of DurbinWatson (test DW) with the following conditions:

1. If $\mathrm{d}<\mathrm{dl}$, means there is positive autocorrelation

2. If $\mathrm{d}>(4-\mathrm{dl})$, mean there autokorelasi negative

3. If $\mathrm{du}<\mathrm{d}<(4-\mathrm{dl})$, means there is no autocorrelation

4. If $\mathrm{dl}<\mathrm{d}<\mathrm{du}$ or $(4-\mathrm{du})$, meaning it can not be concluded

$\mathrm{du}$ and $\mathrm{dl}$ value can be obtained from statistical tables Durbin Watson who rely number of observations and many variables explained.

Table 5 Test Autocorrelation

\begin{tabular}{lrrrrr}
\hline Model & R & R Square & Adjusted R Square & Std. Error of the Estimate & Durbin-Watson \\
\hline 1 & $.666^{\text {a }}$ & .443 & .379 & 1.59384 & 1,777 \\
\hline
\end{tabular}


a. Predictors: (Constant), Lag_Y, services, products, revenue sharing, religiosity

b. Dependent Variable: saving decisions

From the above output DW generated value obtained from the regression model is 1,777. While the DW table by 0.05 and the number of data $(\mathrm{n})=48$, and $\mathrm{k}=4$ ( $\mathrm{k}$ is the number of independent variables) obtained sebesar1,3779 dL and dU value of 1.7214 (see attached). Thus, it appears that $\mathrm{du}(1.7214)<\mathrm{DW}(1,777)<(4-\mathrm{dl}(1.3779))$, means there is no autocorrelation.

\section{Linearity test}

the linearity test aims to determine whether the two variables have a linear relationship or not significance. The test is usually used as a prerequisite in the correlation or regression analysis linear. The test in SPSS by using the Test for Linearity with the significance level of 0.05 . Two variables are said to have a linear relationship when significance (Linearity) is less than 0.05 .

Table 6 Test Linearity between Variable Products with Customer Saving Decision

\begin{tabular}{|c|c|c|c|}
\hline \multicolumn{4}{|c|}{ ANOVA table } \\
\hline & & & ig. \\
\hline \multirow[t]{3}{*}{ saving decision *product } & Between Groups & (Combined) & .089 \\
\hline & & Linearity & .004 \\
\hline & & Deviation from Linearity & .730 \\
\hline
\end{tabular}

From the above output can be seen that the significant value on Linearity of 0.004 . Because of the significance of less than 0.05 , it can be concluded that the variable product and saving decisions linear relationship exists.

Table 7 Test of linearity between variables Saving Customer Service by Decree

\begin{tabular}{|c|c|c|c|}
\hline \multicolumn{4}{|c|}{ ANOVA table } \\
\hline & & & Sig. \\
\hline \multirow[t]{3}{*}{ saving decision *service } & Between Groups & (Combined) & .009 \\
\hline & & Linearity & .000 \\
\hline & & Deviation from Linearity & .268 \\
\hline
\end{tabular}

From the above output can be seen that the significant value on Linearity of 0.00 . Because of the significance of less than 0.05 , it can be concluded that the service variable and saving decisions linear relationship exists.

Table 8 Test Linearity between Variable Ratio Sharing with Customers Saving Decision

\begin{tabular}{|c|c|c|}
\hline \multicolumn{3}{|c|}{ ANOVA table } \\
\hline & & Sig. \\
\hline \multirow[t]{3}{*}{ saving decision * sharing ratio Between Groups } & (Combined) & .000 \\
\hline & Linearity & .000 \\
\hline & Deviation from Linearity & .015 \\
\hline
\end{tabular}


From the above output can be seen that the significant value on Linearity of 0.000 . Because of the significance of less than 0.05 , it can be concluded that the sharing ratio between variable and saving decisions linear relationship exists.

Table 9 Test of linearity between variables Religiosity with Customer Saving Decision

\begin{tabular}{lllr}
\hline \multicolumn{3}{c}{ ANOVA table } \\
\hline saving decision * religiosity & Between Groups & (Combined) & Sig. \\
& & Linearity & .000 \\
& & Deviation from Linearity & .000 \\
& & .001 \\
\hline
\end{tabular}

From the above output can be seen that the significant value on Linearity of 0.000 . Because of the significance of less than 0.05 , it can be concluded that between religiosity and decision variables saing that have linear relationship.

\section{Multiple Linear Regression Analysis}

Multiple linear regression analysis is a linear relationship between two or more independent variables $(\mathrm{X} 1, \mathrm{X} 2, \ldots . \mathrm{Xn})$ with the dependent variable $(\mathrm{Y})$. This analysis is to determine the direction of the relationship between the dependent and independent variables are each independent variable associated positive or negative, and to predict the value of the dependent variable when the independent variable value increased or decreased. The data used is usually an interval or ratio scale.

Multiple linear regression equation as follows:

$\mathrm{Y}^{\prime}=\mathrm{a}+\mathrm{b} 1 \mathrm{x} 1+\mathrm{b} 2 \mathrm{X} 2+\mathrm{b} 3 \mathrm{X} 3+\mathrm{b} 4 \mathrm{X} 4$

Description:

$\mathrm{Y}^{\prime} \quad=$ Decision Saving (dependent variable (value predicted))

$\mathrm{X} 1 \quad=$ Product

$\mathrm{X} 2=$ Services

$\mathrm{X} 3=$ Ratio for the results

$\mathrm{X} 4=$ Religiusitas

a $\quad=$ constants (value $Y$ 'if $X 1, X 2 \ldots \ldots \mathrm{Xn}=0$ )

$\mathrm{b} \quad=$ regression coefficient (value increase or decrease)

Table 10 Analysis Linear regression

\begin{tabular}{|c|c|c|c|c|c|c|c|}
\hline \multicolumn{8}{|c|}{ coefficients $^{\mathrm{a}}$} \\
\hline \multirow{2}{*}{\multicolumn{2}{|c|}{ Model }} & \multicolumn{2}{|c|}{ unstandardizedcoefficients } & \multicolumn{2}{|c|}{$\begin{array}{l}\text { Standardized } \\
\text { coefficients }\end{array}$} & \multirow[b]{2}{*}{$\mathbf{t}$} & \multirow[b]{2}{*}{ Sig. } \\
\hline & & B & Std. Error & Beta & & & \\
\hline 1 & (Constant) & 1,183 & 4,261 & & & .278 & .783 \\
\hline & Product & .270 & .153 & & .252 & 1,767 & .084 \\
\hline & Services & . 148.076 .508 .614 & & & & & .075 \\
\hline & revenue sharing & .369 & .153 & & .372 & 2,422 & .020 \\
\hline & Religiosity & .178 & .145 & & .198 & 1,232 & .225 \\
\hline & Lag_Y & .128 .064 .513 .611 & & & & & .066 \\
\hline
\end{tabular}


a. Dependent Variable: saving decisions

regression equation as follows:

$Y^{\prime}=1.183+0,270 X 1+0,075 X 2+0,369 X 3+0,178 X 4$

regression equation above can be explained as follows:

1. Constants of 1,183; meaning that if the factors of products, services, revenue sharing and religiosity $(\mathrm{X} 1, \mathrm{X} 2, \mathrm{X} 3, \mathrm{X} 4)$, the value is 0 , then the customer decision saving $\left(\mathrm{Y}^{\prime}\right)$ value was $118.3 \%$

2. regression coefficient product $(\mathrm{X} 1)$ of $0,270 \mathrm{X} 1$; meaning that if another independent variable value is fixed and products increased $1 \%$, then the customer decision saving ( $\left.\mathrm{Y}^{\prime}\right)$ will increase by $27.0 \%$. The coefficient is positive, meaning a unidirectional relationship between the products at the customer's decision to save, the better the product, the higher the customer's decision to save.

3. The regression coefficient service variable (X2) 0.075; meaning that if another independent variable value is fixed and services rose $1 \%$, then the customer's decision to save. ( $\left.Y^{\prime}\right)$ will be increased also by $7.5 \%$. The coefficient is positive, meaning a unidirectional relationship between the service and the customer's decision to save, the better the service, the higher the customer's decision to save.

4. The regression coefficient variable profit sharing ratio (X3) equal to 0.369; meaning that if another independent variable value is fixed and profit-sharing ratio increased $1 \%$, then the customer decision saving $\left(\mathrm{Y}^{\prime}\right)$ will be increased also by $36.9 \%$. The coefficient is positive, meaning a unidirectional relationship between revenue sharing with the customer's decision to save, the better the profit sharing ratio, the higher the customer saving decission.

5. The regression coefficient of religiosity variable (X4) of 0.178 ; meaning that if another independent variable value is fixed and religiosity rose $1 \%$, then the customer decision saving ( $\left.Y^{\prime}\right)$ will be decreased by $17.8 \%$. The coefficient is positive, meaning a unidirectional relationship between religiosity and saving customer's decision, the better the religiosity, the higher the customer saving decission.

\section{Multiple Correlation Analysis ( $R$ )}

This analysis is used to determine the relationship between two or more independent variables $(\mathrm{X} 1, \mathrm{X} 2, \ldots \mathrm{Xn})$ to the dependent variable $(\mathrm{Y})$ simultaneously. This coefficient shows how much relations between the independent variables $(\mathrm{X} 1, \mathrm{X} 2, \ldots . . . \mathrm{Xn})$ simultaneously on the dependent variable $(\mathrm{Y})$. $\mathrm{R}$ value ranges from 0 to 1 , the closer the value of 1 means the relations stronger, otherwise the value closer to 0 , then the relations weakened.

According Sugiyono (2007), guidelines to provide interpretation of the correlation coefficient as follows:

$\begin{array}{lll}\text { to } & 0.000 .199 & =\text { very low } \\ \text { to } & 0.200 .399 & =\text { low } \\ .40 & \text { to } .599 & =\text { medium } \\ \text { to } & 0.600 .799 & =\text { strong } \\ \text { to } & 0.801 .000 & \text { = very strong }\end{array}$

From the results of the regression analysis, a look at the output model summary and presented as follows:

Table 11 results of Multiple Correlation analysis

\begin{tabular}{|c|c|c|c|c|c|}
\hline \multicolumn{6}{|c|}{ Model summary ${ }^{\mathbf{b}}$} \\
\hline Model & $\mathbf{R}$ & R Square & Adjusted R Square & Std. Error of the Estimate & Durbin-Watson \\
\hline
\end{tabular}




\begin{tabular}{|c|c|c|c|c|c|}
\hline 1 & $.666^{\mathrm{a}}$ & .443 & .379 & 1.59384 & 1,777 \\
\hline
\end{tabular}

The above table for 0,666 . Hal $\mathrm{R}$ figures obtained indicate that there is a strong relationship between the variables of products, services, revenue sharing and religiosity with the customer's decision to save.

\section{Analysis of determination (R2)}

in the determination of analysis used multiple linear regression to determine the percentage contribution of the influence of the independent variables (X1, X2, ..... Xn) simultaneously on the dependent variable (Y). This coefficient indicates the percentage of variation of the independent variables used in the model is able to explain the variation of the dependent variable. R2sama to 0 , then there is no iota of impact that the percentage contribution of independent variables on the dependent variable, or a variation of the independent variables used in the model does not explain the slightest variations in the dependent variable. Instead R2sama to 1, then the percentage contribution of influence given the independent variable on the dependent variable was perfect, or variations of the independent variables used in the model explains $100 \%$ of the variation of dependent variables.

From the results of the regression analysis, a look at the output model summary and presented as follows:

Table 12 Analysis of Determination

\begin{tabular}{lllll}
\hline Model & R & R Square & Adjusted R Square & $\begin{array}{c}\text { Std. Error of the } \\
\text { Estimate }\end{array}$ \\
\hline 1 & $.666^{\mathrm{A}}$ & .3791 .59384 & .443 \\
\hline
\end{tabular}

Based on the table above figures obtained R2 (R Square) of 0.443 or $(44.3 \%)$. This shows that the percentage contribution of the influence of the independent variables (products, services, revenue sharing and religiosity) on the dependent variable (the customer's decision to save) by $44.3 \%$. Or variations of the independent variables used in the model (product, service, revenue sharing and religiosity) was able to explain $44.3 \%$ of the variation of dependent variables (saving customer's decision). While the remaining $55.7 \%$ influenced or explained by other variables not included in this research model.

Adjusted R Square R Square that has been adjusted, this value is always smaller than $\mathrm{R}$ Square and this figure could have negative. Based price Santoso (2001) that for regression with more than two independent variables used Adjusted R2 as the coefficient of determination.

Standard Error of the Estimate is a measure of the number of errors in a regression model to predict the value of Y. The result of regression can nilai1.59384 or 159\% (the value of the customer's decision to save), it means the number of errors in the prediction of the customer's decision saving $159 \%$. As a guidelines if the standard error of the estimate is less than the standard deviation of $Y$ (2.02178), then the better the regression model to predict the value of $Y$.

\section{Test Regression Coefficients Together ( $F$ test)}

This test is used to determine whether the independent variables $(\mathrm{X} 1, \mathrm{X} 2 \ldots . \mathrm{Xn})$ together significantly influence the dependent variable $(\mathrm{Y})$. Or to determine whether the 
regression model can be used to predict the dependent variable or not. Significant means that the relations can apply to the population (generalisable). From the results of regression analysis output value $\mathrm{F}$ as in Table 13 below.

Table 13 Test Results F

\begin{tabular}{llrrrrr}
\hline \multicolumn{5}{c}{} & \multicolumn{5}{c}{ ANOVA $^{\mathbf{b}}$} & & \\
\hline Model & & Sum of Squares & df & Mean Square & F & Sig. \\
\hline 1 & Regression & $17,3946,847.000$ & 5 & & $86,970^{\mathbf{a}}$ \\
& Residual & 109234 & 43 & 2,540 & \\
& Total & 196204 & 48 & & \\
& & & & & \\
\hline
\end{tabular}

a. Predictors: (Constant), Lag_Y, services, products, revenue sharing, religiosity

b. Dependent Variable: of saving decision

Stages to conduct the F test is as follows:

1. Formulate Hypothesis

Ho: There is no significant effect between the products, services, revenue sharing and religiosity together to save the customer's decision.

Ha: There is a significant effect between the products, services, revenue sharing and religiusitas together to save the customer's decision.

2. Determining the significance level

The level of significance using $a=5 \%$ ( $5 \%$ significance or 0.05 ). Based on the above table it can be seen that the significance level of 0.000 for the variable product. Rated 0.00 $<0.05$ then Ho is rejected, meaning that there are significant effect between the products, services, revenue sharing and religiusitas together to save the customer's decision. So from this case can be concluded that the products, services, revenue sharing and religiusitas together influence the customer's decision to save in BSM KC Singkawang.

Partial regression coefficient test ( $t$ test)

This test is used to determine whether the independent variable in the regression model $(\mathrm{X} 1, \mathrm{X} 2, \ldots . . \mathrm{Xn})$ partially significant effect on the dependent variable $(\mathrm{Y})$.

From the results of the regression analysis output can be presented as follows:

Table 14 Test $t$

\begin{tabular}{|c|c|c|c|c|c|c|}
\hline \multicolumn{7}{|c|}{ Coefficients $^{\mathrm{a}}$} \\
\hline \multirow[b]{2}{*}{ Model } & & \multicolumn{2}{|c|}{ unstandardizedCoefficients } & \multicolumn{2}{|c|}{$\begin{array}{l}\text { Standardized } \\
\text { Coefficients }\end{array}$} & \multirow[b]{2}{*}{ Sig. } \\
\hline & & $\overline{\mathbf{B}}$ & Std. Error & Beta & $\mathbf{t}$ & \\
\hline \multirow[t]{6}{*}{1} & (Constant) & 1,183 & 4,261 & & .278 & .783 \\
\hline & product & .270 & .153 & .252 & 1767 & .084 \\
\hline & care & \multicolumn{4}{|c|}{. 148.076 .508 .614} & .075 \\
\hline & revenue sharing & .369 & .153 & .372 & 2,422 & .020 \\
\hline & religiosity & .178 & .145 & .198 & 1,232 & .225 \\
\hline & Lag_Y & \multicolumn{4}{|c|}{.128.064.513.611 } & .066 \\
\hline
\end{tabular}

a. Dependent Variable: decision-saving

Measures following testing:

1. Testing Product variable regression coefficient

a. Determining Hypothesis

Ho: Partially no significant influence between products with saving decision. 
Ha: Partially no significant effect among the products with the decision of saving.

b. Determining the level of significance

The significance level used $=5 \%$. Based on the above table to the variable level of significance for 0,084 products in which the value of $0.084>0.05$ then Ho is accepted, that is partially no significant effect among the products with the customer's decision to save. So from this case can be concluded that partial product does not affect the customer's decision to save Bank Syariah Mandiri KC Singkawang.

2. Testing Services variable regression coefficient

a. Determining Hypothesis

Ho: Partially no significant influence between service with the customer's decision to save

Ha: Partially no significant effect between service with the customer's decision to save

b. Determining the level of significance

using a significance level of $=5 \%$. The level of significance used $=5 \%$. According to the table above a significance level of 0.614 for the variable service, where values of $0.614>$ 0.05 then Ho is accepted, that is partially no significant influence between service with the customer's decision saving. So of this case can be concluded that partial service has no effect to the customer's decision to save Bank Syariah Mandiri KC Singkawang.

3. Testing regression coefficient variable revenue sharing

a. Determining Hypothesis

Ho: Partially no significant effect between revenue sharing with the customer's decision to save

Ha: Partially no significant effect between revenue sharing with the customer's decision to save

b. Determining the level of significance

level of significance using a $=5 \%$. The level of significance used $=5 \%$. According to the table above the level of significance for the variable profit-sharing ratio of 0,020 , where the value of $0.020<0.05$ then Ho is rejected, meaning that partially there is significant influence between revenue sharing with the customer's decision saving. So of this case can be concluded that partial sharing ratio affect the customer's decision to save Bank Syariah Mandiri KC Singkawang.

4. Testing religiosity variable regression coefficient

a. Determines Hypothesis

Ho: Partially no significant effect between religiosity and saving customer's decision

Ha: Partially no significant effect between religiosity and saving customer's decision

b. Determining the level of significance

using a significance level of $=5 \%$. The level of significance used $=5 \%$. According to the table above for the significance level of 0.225 religiosity variable, where the value of $0.225>0.05$ then Ho is accepted, meaning that partially there is no significant effect between religiosity and the customer's decision saving. So of this case can be concluded that partial religiusitas doesn't effect on saving customer's decision in Bank Syariah Mandiri KC Singkawang. 


\section{Conclusion}

Conclusion

Simultaneously no affect between variable products, services, revenue sharing and religiosity of the customer's decision to save in the customer's decision to save Bank Syariah Mandiri KC Singkawang. Simultaneously influence the level of $44.30 \%$. This means that all independent variables are together able to explain the decision of customers to save in Bank Syariah Mandiri KC Singkawang $44.30 \%$ and the rest of $55.70 \%$ influenced by other factors.

Based on the regression results obtained regression coefficient variable product of 0.270 and $p$-value $=0.084$. At the level of significance of $5 \%(0.05)$, then $p$-value $=0.084>0.05$, so it can be concluded that the product factor partially positive but not significant to the decision of customers to save in Bank Syariah Mandiri KC Singkawang. It can be concluded that the diversity of products or product quality offered is not a factor considered by customers in deciding to save at Bank Syariah Mandiri KC Singkawang.

Based on regression result obtained regression coefficient of service variable equal to 0.075 and p-value $=0.614$. At the level of significance of $5 \%(0.05)$, then $p$-value $=0.614>0.05$, so it can be concluded that the service factor partially positive but not significant to the decision of customers to save in Bank Syariah Mandiri KC Singkawang. It can be concluded that service variable is not an advantage for Bank Syariah Mandiri KC Singkawang considered when customers decide to save in Bank Syariah Mandiri KC Singkawang.

Based on the regression results obtained regression coefficient variable profit sharing ratio of 0.369 and $p$-value $=0.020$. At the level of significance of $5 \%(0.05)$, then $p$-value $=0.020$ $<0.05$, so it can be concluded that the partial revenue-sharing ratio factor offered by Bank Syariah Mandiri KC Singkawang has a positive and significant effect on the decision of customers to save at Bank Syariah Mandiri KC Singkawang. In this case the profit sharing ratio factor has positive and significant effect, it can be said that the profit sharing ratio in Bank Syariah Mandiri KC Singkawang is considered competitive and fair. In addition, the views of customers on sharia banks that do not recognize the interest of banks as in conventional banks. Interest banks include the category of usury and haram in Islamic sharia. Given that view encourage customers to invest in banking that takes into account Islamic ethics and morals.

Based on the regression results obtained regression coefficient variable religiosity of 0.178 and $p$-value $=0.225$. At the level of significance of $5 \%(0.05)$, then $p$-value $=0.225>0.05$, so it can be concluded that the factor of religiosity has a positive but not significant effect on the decision of customers to save at Bank Syariah Mandiri KC Singkawang. The insignificant factor of religiosity is probably due to the customers in choosing a bank which in this case sharia bank, they prefer economic rational rather than religious factor.

Advice

In the next study need to increase the number of subjects in the study and add other variables more appropriate in influencing the decision of customers save. Considering the factor of product, service, profit sharing ratio and religiosity together only give a contribution of $44.30 \%$ influence to the decision of customers to save in Bank Syariah Mandiri KC Singkawang. There is still a considerable percentage of other factors namely Bank Syariah Mandiri KC Singkawang. 
The need for the participation of parents, religious leaders, and scientists to realize the integration of equality of perception in advancing Islamic banking and socialization of Islamic banks to all levels of society. It is expected to trigger the public to be more confident about the performance of sharia banking and materialize the decision to save the community in sharia banks.

\section{References}

Kotler, Phillip dan Kevin, Lane Keller. (2007). Manajemen Pemasaran. Edisi 12. PT Indeks. Jakarta

Lubis, Irsyad. (2010). Bank dan Lembaga Keuangan Lain. USU Press. Field.

Machmud, Amir dan Rukmana. (2010). Bank Syariah (Teori, Kebijakan dan Studi Empiris di Indonesia). Erland. Jakarta.

Priyatno, Dwi. (2008). Mandiri Belajar SPSS, Mediakom, Yogyakarta.

Riduwan.(2010). Metode dan Teknik Menyusun Proposal Penelitian. Alfabeta. Bandung.

Soemitra, Andri. (2009). Bank dan Lembaga Keuangan Syariah. Cetakan kedua. Prenada Media. Jakarta.

Sudarsono, Heri. (2007).Bank dan Lembaga Keuangan Syariah Deskripsi dan Ilustrasi. Edition II. Ekonosia. Yogyakarta. 